William Wright Smith. The Gunning Victoria Jubilee Prize (1940-44) was presented to Prof. H. W. Turnbull, regius professor of mathematics in the University of St. Andrews, and the Makdougall-Brisbane Prize (1942-44) jointly to Prof. Max Born, Tait professor of natural philosophy in the University of Edinburgh, and Dr. H. W. Peng. After the presentations Prof. Sydney Chapman, at the request of the Council and in terms of the Bruce-Preller Lecture Fund, addressed the Society on "The Earth's Magnetism".

\section{Blackwell Prize and the Senior Hume Brown Prize in Scottish History}

Two scientific workers, well known in the fields of scientific history and social technology, have just been awarded two unusual distinctions. Dr. Archibald Clow, of the Department of Chemistry of the University of Aberdeen, has been awarded the Blackwell Prize for a study of chemical contributions to industrial development. Dr. Clow and his wife, Nan L. Clow, have been carrying out research for several years on the contribution of chemistry to human welfare and development in the era of the industrial revolution, and the manuscript of the book in which they have embodied the results of their researches has been judged an outstanding contribution to history by the University of Edinburgh, which has awarded them the senior Hume Brown Prize in Scottish history. Both authors are graduates in arts and science of the University of Aberdeen, and Mrs. Clow particularly is well known for her contribution to the development of the scientific film society movement. Dr. Clow is a member of council of the Scientific Film Association. Dr. Clow is now working with the B.B.C., where he is taking charge of scientific broadcasts in a new programme to be produced in the early autumn.

\section{Awards of the Veterinary Educational Trust}

THE Council of the Veterinary Educational Trust has awarded a Senior Wellcome Fellowship for Veterinary Research to Mr. Christopher W. Ottaway. After qualifying in December 1931, Mr. Ottaway was in veterinary practice for three years. He then entered the Anatomy Department, Royal Veterinary College, as a demonstrator and is now senior assistant in the Department. He has worked in the School of Veterinary Anatomy, Leipzig, and in the Depart. ment of Anatomy, Brno University Veterinary School, and has published a number of papers on anatomical problems concerned with domestic animals. His research work under the fellowship will be conducted at the Zoological Laboratories, University of Cambridge, and will be concerned with an investigation into the mechanics of the limbs of domestic animals and the factors which predispose to lameness and other diseased conditions.

The Council has also awarded a Welleome Fellowship for Veterinary Research to Mr. Herbert Williams Smith. Mr. Williams Smith qualified in 1941 and has spent two years in private practice as an assistant. Since 1943 he has been an assistant veterinary investigation officer at the University College of North Wales, Bangor. He has contributed to the technical Press on the examination of milk samples for mastitis, and on the coagulase test for staphylococci. He has recently completed the examination of more than two hundred strains of staphylococci of animal origin with particular reference to determining criteria of pathogenicity. His research under the award will be concerned with the epidemiology of staphylococcal infections in animals, and will be conducted under Prof. G. S. Wilson at the London School of Hygiene and Tropical Medicine.

\section{Conference on Automatic Controlling and Record- ing of Chemical and Other Processes}

The Institution of Chemical Engineers, the Institute of Physics and the Chemical Engineering Group of the Society of Chemical Industry announce that the one-day joint conference on "Instruments for the Automatic Controlling and Recording of Chemical and Other Processes", which was postponed in September last, will take place at the Royal Institution, London, on October 19, 1945. The purpose of the conference is to promote the inter change of knowledge and experience between those using automatic controllers and recorders in different fields and to encourage collaboration between physicists and chemical engineers. The conference will be open without charge to all interested, whether members of the organizing bodies or not. Further particulars will be sent in September to those sending a request for them to the Organizing Secretary, Joint Conference, c/o the Institution of Chemical Engineers, 56 Victoria Street, London, S.W.1. As there have been so many changes of address, those who previously asked for further particulars are asked to repeat their request.

\section{Announcements}

Sir Lawrence Braga is lecturing in Paris at the Sorbonne, under the auspices of the British Council, on "X-Ray Analysis, Past, Present and Future", "The Strength of Metals", and "X-Ray Optics". The visit was arranged in response to a request from French men of science. These lectures conclude a series arranged by the British Council in France since February, but the Council is assisting the British Institute in Paris in making arrangements for future lecturers.

Mr. A. L. L. Baker has been appointed to the University chair of concrete technology tenable at Imperial College of Science and Technology. During the War he has been consultant to the War Office and Admiralty for marine works, and since March 1945 he has been employed in the Chief Scientific Adviser's Division of the Ministry of Works.

Dr. E. W. Sмгтн has been elected president of the Institute of Fuel for the year ending October 1946 ; this will be his third year of office. Mr. J. F. Ronca, member of Council, has been elected honorary secretary of the Institute.

A British Medical Exhibition arranged by the British Council was opened at the Sao Jose Hospital in Lisbon last month by the Portuguese UnderSecretary for Education. The Exhibition includes books and instruments, and British medical films have been shown. The Portuguese Minister of Education sent a message paying tribute to the work of the British Council and its institutes in Portugal, and expressing the hope that more such exhibitions would be arranged.

ERratum.-The author of the communication "Naga, Naja, Naia or Naya?" published in Nature of April 14, p. 457, is W. V. D. Pieris, not "Picris", as printed ; throughout the note, the word 'Singhalese' should be 'Sinhalese'. 